Article

\title{
Employee Profit Sharing: A Moral Obligation or a Moral Option?
}

Franz Giuseppe F. Cortez

\begin{abstract}
This paper will explore the ethics of employee profit sharing. It will challenge the view that profit sharing is and will always remain a moral option of the employer - that it has no obligatory character whatsoever. Normative arguments grounded on justice, equity, rights, and general welfare are necessary, but they are not sufficient to account for the ethics of employee profit sharing. Building upon the insights of some meta-ethicists, I will show that granted that employee profit sharing is not morally obligatory, to call it morally optional in all instances is simplistic and evasive of possible nuances in moral life and the complexities of the business sphere.
\end{abstract}

Keywords: profit sharing, supererogation, moral judgment, metaethics

\section{Introduction}

Y ou are the owner of a medium enterprise. In the 20 years of its existence, your profits have always been over and above your target. Cocovered your capital in less than 2 years of the existence. Costs and provisions for expansion are covered. By all accounts, your efforts and risks are rewarded. You have enriched yourself because of this business. You have profits more than what you and your business need. Are you morally obliged to share a portion of these profits to your employees?

The standard instinctive reply (and probably, the dominant one) to this question is that the business owner has no moral obligation at all. If he is neither violating any labor law nor is he breaking any terms of contract between him and his employees, he is not morally required to share anymore.

(C) 2017 Franz Giuseppe F. Cortez

https://www.kritike.org/journal/issue 21/cortez december2017.pdf

ISSN 1908-7330 
Its performance is beyond moral duty. Not to share does not incur any moral failure on the employer's part. ${ }^{1}$

Moreover, as far as the legal obligation is concerned, it can be said that almost all societies do not have a law that requires the employer to implement a profit sharing scheme. And so generally speaking, profit sharing is not a legal obligation. ${ }^{2}$ But of course, a basic dictum in ethics is that legality is different from morality. In the court of law, an employer may not be obligated to share the profits. But in the court of morality and conscience, does the proposition remain uncontroversial and defensible? ${ }^{3}$

This paper will explore the ethics of employee profit sharing. It will challenge the view that profit sharing is and will always remain a moral option of the employer - that it has no obligatory character whatsoever. I will start with some important clarifications of the concept of employee profit sharing. Then, I will survey some notes of scholars regarding the ethics of employee profit sharing. Afterwards, I will present my take on this practice

1 "Although there are a lot of economic reasons to share profits with employees, from an ethical point of view there can be no obligation for a company to do that. Therefore, this would be an act of generosity of management towards employees." Stefan Georgescu and Loredana Bosca, "Management's Duty towards Employees: A Business Ethics Approach," in Proceedings of the $7^{\text {th }}$ International Management Conference (Bucharest, Romania: 7-8 November 2013), 161.

According to Benjamin Masse, "Has it (UAW [United Automobile Workers]) a right to demand profit-sharing for workers? If there is a question of moral right, a right founded in the natural law, the answer is 'no.' Workers have a right to a wage ... But once employers have discharged this duty they have no further obligation in justice to their employees." Quoted in Gerard Rooney, "The Right of Workers to Share in Ownership, Management, and Profits," in Catholic Theological Society of America: Proceedings of the Eighteenth Annual Convention (St. Louis, Missouri, 24-27 June 1963), 143.

"Payment of a profit-sharing bonus to non-management employees typically takes place at the discretion of the company and does not constitute an entitlement, although if it is paid routinely and year after year, employees may come to count on it as part of their compensation." Anaxos Santore, "Profit Sharing," in Encyclopedia of Small Business, $4^{\text {th }}$ ed., ed. by Virgil L. Burton III (Michigan, USA: GALE Cengage Learning, 2010), 1012.

${ }^{2}$ However, even if it is not a legal obligation, it must be noted that there are attempts to strengthen it in the legal sphere. For example, the largest companies in France are mandated by law to establish their profit sharing programs. The law covers companies with at least 50 employees for 6 months during the fiscal year. "Below this size requirement, the profit-sharing plan is optional. Companies who decide voluntarily to set up a profit sharing plan can benefit from the tax exemption concerning the sums distributed to the employees." It makes one wonder what could spur this attempt by the French government to establish the practice as a legal obligation. See AFIGEC, "Profit Sharing Plan in France," in AFIGEC: Expert Comptable and Conseil,

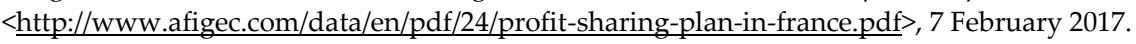

${ }^{3}$ In a dominant capitalistic society, one can also observe an easy way of interchanging the notion of legal and moral. Moral obligation is oftentimes tied to the notion of legal obligation so that the distinction between the two is usually blurred. Furthermore, the right to property is at once invoked in an ordinary evaluation of the non-obligatory character of employee profit sharing. This dominant thinking in the capitalistic society can be a hindrance to an attempt for clarifying the moral aspect of employee profit sharing.

(c) 2017 Franz Giuseppe F. Cortez

https://www.kritike.org/journal/issue 21/cortez december2017.pdf

ISSN 1908-7330

(c) $)$ BY-NC-ND 
using some moral thinkers' analyses of the meaning of moral obligation and moral option. I will end with some concluding remarks.

\section{Clarifying the Concept of Employee Profit Sharing}

Profit sharing can take two forms: employee profit sharing (EPS) and shareholder profit sharing (SPS). As the terms obviously imply, EPS is the profit shared with and among the employees while SPS is the sharing of profits among people who "provide capital for and derive returns in the form of profits and dividends from companies." 4 The concern of this paper is EPS and not SPS. And when I use the term profit sharing, I refer simply to EPS.

In the field of economics, there are also scholars who have considered profit sharing schemes as a kind of supplement or even alternative to the generally accepted wage scheme. For example, as early as 1887 the American economist Franklin Giddings suggested that a profit sharing scheme is economically and morally better than the wage system. ${ }^{5}$ In the modern era, Giddings' suggestion is best echoed by the studies done by Martin Weitzman. Concerned with the economic problems of joblessness and high inflation, Weitzman proposed what is now known as Share Economy Theory. In his macroeconomic analysis, he suggested that an economy based on the principles of profit sharing has the natural inclinations towards sustainability and non-inflationary employment compared to an economy of wage capitalism. ${ }^{6}$ In a later publication, Weitzman clarified that profit sharing scheme would not completely replace the wage system. Rather, he suggested a fundamental reform in employee-compensation schemes. ${ }^{7}$

Because this issue has caught the attention of scholars and practitioners alike, my concern for EPS does not cover this economic concern of supplementing the wage system with a profit sharing scheme. This is not my expertise. Thus, when I talk about EPS on this paper, I do not specifically refer to what Giddings expounded and what Weitzman subsequently elaborated and defended.

It is of utmost importance to define the term profit sharing because throughout its known history, various definitions have already been offered. One of the earliest formulations comes from the 1889 International Cooperative Congress held in France. The congress stated that profit sharing involves "an

\footnotetext{
${ }^{4}$ John Reynolds, Sharing Profits: The ethics of remuneration, tax and shareholder returns (UK. Palgrave MacMillan, 2015), 73.

${ }^{5}$ Franklin H. Giddings, "The Theory of Profit-Sharing," in The Quarterly Journal of Economics 1:3 (1887), 367.

${ }^{6}$ Martin Weitzman, "The Simple Macroeconomics of Profit Sharing," in American Economic Review 75 (1985), 937-953.

7 Martin Weitzman, The Share Economy: Conquering Stagflation (Cambridge: Harvard University Press, 1984).
}

(C) 2017 Franz Giuseppe F. Cortez https://www.kritike.org/journal/issue 21/cortez december2017.pdf ISSN 1908-7330 
agreement freely entered into, by which the employees receive a share, fixed in advance, of the profits." 8 In 1916, the United States Bureau of Labor Statistics came up with a report about the practice of profit sharing in the U.S. According to the report, the commonality of all the plans is "the understanding among all concerned that the shares in the profit or the bonuses paid to the employees are separate and distinct from the employees' regular earnings, subject to change and withdrawal by the employer without notice, and with the qualifications for participation fixed at his discretion." 9 In 1920, the United Kingdom Ministry of Labor produced their study about the practice of profit sharing in the U.K. The study defines profit sharing as "an agreement between an employer and his employees whereby the latter receive, in addition to their wages or salaries, a share, fixed beforehand, in the profits of the undertaking." 10 Another source of a definition is the Council of Profit Sharing Industries formed in 1947 in the U.S. According to the council, profit sharing is "any procedure under which an employer pays to all employees, in addition to good rates of regular pay, special current or deferred sums, based not only upon individual or group performance, but on the prosperity of the business as a whole." 11

From these various definitions, some features can be extracted that are relevant in my discussion. First, obviously what must be shared is the profit of the business. If it so happens that an employee is also a shareholder, then the profit that he/she receives can be technically called a dividend and not a profit received by an employee qua an employee. Second, those who should share cannot be the top executives and management only. It must include almost all (if not all) employees who have met certain criteria of eligibility such as years of service in the company. Third, the profit to be shared must be fixed in advance. Fourth, profit sharing is not a substitute for but a supplement to just wage and decent working condition. ${ }^{12}$ Fifth, profit sharing is not necessarily the same with bonuses understood simply as reward or incentive. The motive of sharing profits may not necessarily be the

\footnotetext{
${ }^{8}$ As quoted in Borris Emmet and United States Bureau of Labor Statistics, Profit Sharing in the United States: Bulletin of the United States Bureau of Labor Statistics 208 (Washington, D.C.: Government Printing Office, June 1916), 8, note 2.

${ }^{9}$ Ibid., 6.

10 "Report on Profit Sharing and Co-Partnership in the United Kingdom" (United Kingdom Ministry of Labour, 1920), ii.

${ }^{11}$ J. B. Meier, "Origins and Growth of Profit Sharing and the Council," in Council of Profit Sharing Industries, (1951), 4. As quoted in James H. Quill, Profit Sharing - A Means of Economic Cooperation between Labor, Management, and Government (M.S. Thesis, Chicago: Loyola University, 1954), 6-7.

12 "Any profit-sharing scheme must be based upon a sound foundation of wages. It represents not a substitute for but an addition to wages, and cannot act as a palliative of low wages." Oliver Sheldon, The Philosophy of Management, ed. by Oliver Sheldon, vol. 4 of The Philosophy of Management (London: Routledge, 2003), 153.

(c) 2017 Franz Giuseppe F. Cortez

https://www.kritike.org/journal/issue 21/cortez december2017.pdf

ISSN 1908-7330

(c) BY-NC-ND
} 
same with the motive of giving incentives. Sixth, profit sharing is not wage increase. It implies that if there is no profit for any given period, the employee cannot expect for a share.

\section{Ethics of Profit Sharing}

Various schemes of employee profit sharing find its origin in the $19^{\text {th }}$ century. ${ }^{13}$ The original impetus is not business productivity but social reform. In his study, James Quill finds out that "the profit sharing plans started in France and England were mostly of a social reform type rather than an incentive to increase production."14 In his exhaustive research on financial participation, Daryl D'Art refers to this as the traditional or altruistic perspective wherein employers are generally inspired by Christian, philanthropic and paternalistic sentiments: a feeling of responsibility to act with generosity and nobility towards the less-fortunate. D'Art says further:

Frequently, altruistic practitioners justify their largesse by reference to equity and social justice, or by a claim that employees have a right to share in the profits they help create. For altruistic proponents and practitioners of financial participation, the benefit lies primarily in virtue being its own reward, though there may also be some expectation of more harmonious labourmanagement relations. ${ }^{15}$

As early as 1887, Giddings argues that profit sharing scheme can produce more wealth for the society as compared to the wage system. He further maintains that the demands of distributive justice and equitable distribution of wealth is served better under the system of profit sharing. ${ }^{16} \mathrm{In}$ 1920, the British Ministry of Labour reported that profit sharing is in harmony with equity and with the essential principles underlying all legislation. ${ }^{17}$ In 1924, Oliver Sheldon who was writing on philosophy of business management opines that,

... the value of any [profit sharing] scheme is more likely to reside in the concession to the claims of justice which

${ }^{13}$ Daryl D'Art, Economic Democracy and Financial Participation: A Comparative Study (London: Routledge, 1992), 222.

${ }^{14}$ Quill, Profit Sharing, 2.

${ }^{15}$ D'Art, Economic Democracy and Financial Participation, 218.

${ }^{16}$ Giddings, "The Theory of Profit-Sharing," 367.

${ }^{17}$ See "Report on Profit Sharing and Co-Partnership in the United Kingdom," 3.

(C) 2017 Franz Giuseppe F. Cortez https://www.kritike.org/journal/issue 21/cortez december2017.pdf

ISSN 1908-7330 
it represents than in the immediate results of the payment. Such psychological value may, however, be of greater importance than the more questionable economic value. If profit-sharing can materially contribute to the development of a sense of justice in industry, its value may be immeasurable. ${ }^{18}$

In 1952, Wheeler sees the wisdom of profit sharing as it is rooted in equality of opportunity, the harmonious relationship between capital and labor, and the cultivation of trust between labor and management. He maintains that it is beneficial for all stakeholders in the long run. ${ }^{19}$

From the perspective of the Catholic scholar Francis Cunningham, profit sharing is an issue of equity and thus it pertains to the area of moral obligation. He further declares that even though it is not part of the labor contract, it is a demand of equity aside from the fact that it has many benefits for the various stakeholders. Cunningham further states that profit sharing "appears to be a practical way to effect the greater distribution of wealth and the more widespread ownership so constantly called for by the popes." 20 Then, in the 1963 annual convention of the Catholic Theological Society of America, Gerard Rooney talked about the right of workers to share in profits in terms of the distinction between natural right and acquired right. He says:

Workers do not appear to have a natural right to share profits after receiving a fair wage. But they do appear to have an acquired or earned right, at least by reason of the virtue of social justice, to some share of such profits. The wealth of the corporation is jointly produced by labor and management and capital. It belongs to the economic decisions proper to management to determine how much of the profits should be distributed to stockholders; how much should be used for updating and repairing equipment; how much should be plowed back for plant expansion; how much should be budgeted for rainy days; how much should be granted to executives as special bonuses of merit. But in all these calculations of management, the rights of the workers, who are mainly responsible for the accumulation of this wealth, should not be ignored. They should have some

\footnotetext{
18 Sheldon, The Philosophy of Management, 152.

19 W.H. Wheeler, Jr., "How I Would Introduce a Profit Sharing Plan to a Board of Directors," in Michigan Business Review 3-4 (January 1952), 14-24.

${ }^{20}$ Francis Cunningham, The Christian Life (Oregon: WIPF and Stock, 1959), 546.

(c) 2017 Franz Giuseppe F. Cortez

https://www.kritike.org/journal/issue 21/cortez december2017.pdf

ISSN 1908-7330
}

(c) BY-NC-ND 
share in the profits and they should not be the last to be thought of in the disbursement of profits. In estimating equitable shares of profits, the factors of national redistribution of income, through taxation, as well as pension and welfare funds, should not be overlooked. ${ }^{21}$

In more recent years, scholars such as Priewe and Havighorst observe that "from a socio-political perspective, financial participation is ... expected to raise social integration and to achieve a wider distribution of the wealth generated by the enterprises which workers have helped to produce." 22 Other researchers point to positive effects such as "higher motivation and commitment, lower absenteeism and labor turnover, greater identification of workers with the interests of their firm, greater investment in firm specific human capital, reduced intra-firm conflict and labor management tension, and improvements in work organization." 23

This brief sketch suggests that the moral impulse of EPS was already present even during its infancy days. And this moral impulse took precedence to purely business motives. Essentially, what these scholars underpin are reasons that surface from the concern for justice, fairness and the promotion of general welfare. EPS appears to be a moral obligation because it is what is most beneficial for the society in general, what justice and fairness demand, and what recognition of laborers' rights entails.

But if this is the case, how come that it is not enshrined in the laws as an obligatory practice? This is a topic that deserves a separate attention. Still, a few words can be said. If the original impetus is inclined to social reform and concern for justice, one can suppose that the business proposition of employee profit sharing may simply be an offshoot of the predominance of managerialism which is simultaneous with the rise of the modern corporation. ${ }^{24}$ I suspect further that the moral justifications can be met with counter-arguments using parallel moral reasoning. For example, a utilitarian reasoning can present a case that making EPS obligatory may not really be beneficial (or even be more harmful) for the business organization or for the

${ }^{21}$ Rooney, "The Right of Workers to Share in Ownership, Management, and Profits," 148.

22 J. Priewe and F. Havighorst, Auf dem Weg zur Teilhabergesellschaft? (Bonn: Friedrich Ebert Stiftung, 1999). As cited in Marija Ugarkovic, Profit Sharing and Company Performance (Wiesbaden, Germany: Deutscher Universitats-Verlag, 2007), 2.

${ }^{23}$ Milicia Uvalic, The Pepper Report: Promotion of Employee Participation in Profits and Enterprise Results in the Member States of the European Community (Luxembourg: Office of the Official Publications of the European Communities, 1991), 12.

${ }^{24}$ For a sustained discussion of the managerial perspective of EPS, see D'Art, Economic Democracy and Financial Participation, 218-220.

(C) 2017 Franz Giuseppe F. Cortez https://www.kritike.org/journal/issue 21/cortez december2017.pdf ISSN 1908-7330 
society in the long run. ${ }^{25}$ An appeal to laborers' rights can also be countered by the employer's appeal to his own rights to freedom and property, rights that are so sacred in a predominantly capitalistic society. Finally, justice and fairness can be invoked by both camps. If the employees can state that it is just and fair to share the profits, the employer can also state that it is just and fair not to share it simply because he takes the greatest burden when the business fails. Treating people right can work both ways.

Hence, aside from the traditional normative approach rooted in utilitarian and deontological reasoning, we must still find other theoretical groundings for a deeper appreciation of the obligatory nature of EPS. I suggest an excursion into the field of meta-ethics.

\section{A Meta-Ethical Approach to Employee Profit Sharing}

Another approach in understanding the issue at hand is through the analysis of the notions of moral obligation and moral option. In moral philosophy, this is called meta-ethics, sub-field that focuses on the analysis of moral concepts and their meanings as compared to normative ethics that is directed to the discovery of moral principles to be used to make moral judgments. ${ }^{26}$ Thus, the issue is not only whether employee profit sharing is obligatory or optional in reference to some established ethical theories such as utilitarianism or deontology. Rather, the following questions can also be asked: (1) When can we say that a practice or an act is morally obligatory or simply optional? (2) What do we mean by moral obligation and moral option? (3) If an act is morally obligatory, does it totally preclude the notion of a moral option? (4) Are there instances when what is generally considered as morally optional may cross into the category of what is morally obligatory? Or, are there middle grounds?

Building upon the insights of some meta-ethicists, I hope to show that granted that employee profit sharing is not morally obligatory, to call it morally optional in all instances is simplistic and evasive of possible nuances

${ }^{25}$ For some criticisms side by side with the perceived benefits, see Noel Cahill, "Profit Sharing, Employee Share Ownership and Gainsharing: What Can They Achieve?" (Dublin: National Economic and Social Council, 2000), 9-11.

"Although quite a number of studies have empirically investigated the effects of profit sharing, the picture that emerges is anything but conclusive." Ugarkovic, Profit Sharing and Company Performance, 37.

See also Jack Stack, "The Problem with Profit-Sharing," in Inc. (1 November 2000), $<$ https://www.inc.com/magazine/19961101/1864.html $>, 1$ August 2017.

26 H.J. McCloskey, Meta-Ethics and Normative Ethics (Dordrecht: SpringerScience+Business Media, 1969), 1.

(c) 2017 Franz Giuseppe F. Cortez

https://www.kritike.org/journal/issue 21/cortez december2017.pdf

ISSN 1908-7330

(c) BY-NC-ND 
in moral life. For the task at hand, I do not make a strict distinction between moral duty and moral obligation. ${ }^{27}$

\section{Supererogation and EPS}

A discussion of this sort requires a return to what moral philosophers call supererogation. The term is usually credited to James Urmson's "Saints and Heroes" where he suggested that aside from the traditional (but restrictive) trifecta of obligatory actions, indifferent/permitted actions and wrongful (prohibited) actions, there is a fourth category which he calls supererogatory act wherein the said act has positive moral worth but is at the same time non-obligatory. This supererogation is best manifest in the extraordinary actions of saints and heroes but can also be seen in nonspectacular situations of kindness and generosity performed by ordinary individuals. ${ }^{28}$ What Urmson is pointing out here is that there are actions that go beyond the call of duty and that they are good actions albeit they are not obligatory. Subsequently, David Heyd explains that the supererogatory act has four characteristics. First, it is an act which is neither obligatory nor forbidden. Second, it is not wrong to omit the act. Third, the act is intrinsically good. And lastly, the act is meritorious because it is performed freely for another's good. ${ }^{29}$ Getting into the core of Heyd's characterization of supererogation, Marcia Baron describes the supererogatory act as "beyond duty and they are morally good and praiseworthy." 30 For his part, Gregory Trianosky explains the supererogatory as distinct from the obligatory through the following words: "An obligatory act is an act whose performance is required and whose omission is forbidden. A supererogatory act is an act whose performance is recommended but not required and whose omission is permitted rather than forbidden." 31

Having explained supererogation this way, one can argue right away that an employer's act of sharing the profit to his/her employees is a supererogatory act and thus, an optional or non-obligatory one. First, it is not obligatory because it is usually not part of the contractual agreement between

\footnotetext{
${ }^{27}$ For a discussion of strict distinction, see A. John Simmons, Moral Principles and Political Obligation (Princeton: Princeton University Press, 1979), 11ff. Cited in M.W. Jackson, "Above and Beyond the Call of Duty," in Journal of Social Philosophy 19:2 (1988), 11; 3-12.

${ }^{28}$ James O. Urmson, "Saints and Heroes," in Essays in Moral Philosophy, ed. by A.I. Melden (Seattle: University of Washington Press, 1958).

${ }_{29}$ David Heyd, Supererogation: Its Status in Ethical Theory (Cambridge: Cambridge University Press, 1982), 115.

${ }^{30}$ Marcia Baron, "Kantian Ethics and Supererogation," in The Journal of Philosophy 84:5 (1987), 239.

${ }^{31}$ Gregory Trianosky, "Supererogation, Wrongdoing, and Vice: On the Autonomy of the Ethics of Virtue," in The Journal of Philosophy 83:1 (1986), 26-40.
}

(C) 2017 Franz Giuseppe F. Cortez https://www.kritike.org/journal/issue 21/cortez december2017.pdf ISSN 1908-7330 
the employer and the employee. Each party to a contract is bound only by the terms and conditions of the said contract. The employee cannot oblige the employer to share profits more than what the two parties have agreed upon. Second, employee profit sharing can be deemed to be supererogatory by claiming that it is not wrong to omit the said act. The employer does not violate any right of the employee if he/she does not share the profit beyond the terms and conditions of the contract which usually include just wage and good working condition. The non-performance of the act does not render the employer as unjust or unfair. Third, one may argue that employee profit sharing is supererogatory because it is intrinsically good. It is a virtuous actan act of charity and generosity. Thus, it can never be forbidden, and the employer may always share his/her profits depending upon some relevant considerations. Fourth, employee profit sharing is supererogatory because it is meritorious and is performed freely for the benefit of the employee. It can be said that the employer is not forced and that even in some circumstances that the business motive lies at the very heart of the act, we can still say that there are instances when the employer is freely moved by virtues such as compassion, generosity, and sense of justice.

If understood this way, the argument is settled that an employer's act of profit sharing is not obligatory even though it is highly praiseworthy. Furthermore, it can be said that the employer cannot be imputed with moral blame if he/she opts not to share the profits. To say it directly, employee profit sharing is non-obligatory because it is a supererogatory act which is optional.

\section{Trianosky's View on Supererogation and the Implication to} EPS

In a 1986 article, Gregory Trianosky argues for a nuanced view of supererogation by venturing into the realm of virtue ethics. ${ }^{32}$ He points out the curious case of people who ordinarily make excuses for not performing what is supposed to be supererogatory acts. As examples, Trianosky offers the challenge of supporting a charitable enterprise or joining a group that advances a noble cause. If they are supererogatory, then why does the challenged make excuses to the challenger? Why feel the need to explain or to offer some excuses? Why not simply brush these acts aside because after all, they are non-obligatory? Why is there a feeling of shame or discomfort when refusing to go the extra mile? Trianosky observes that "we seem often to be concerned that morally significant others not disapprove or think less well of us." 33

$$
\begin{aligned}
& { }^{32} \text { Ibid., } 26 . \\
& { }^{3} \text { Ibid., } 28 .
\end{aligned}
$$

(c) 2017 Franz Giuseppe F. Cortez

https://www.kritike.org/journal/issue 21/cortez december2017.pdf

ISSN 1908-7330

(c) BY-NC-ND 
To explain this puzzling case, Trianosky begins with the distinction between two types of negative moral judgments of the person: negative deontic judgment and negative aretaic judgment. Negative deontic judgement refers to the wrongness of an act performed. While negative aretaic judgement is "a judgment about the viciousness of some conative or affective state of the agent." ${ }^{34} \mathrm{He}$ further subdivides negative aretaic judgment into a judgment about the viciousness of standing traits or dispositions and a judgment about the viciousness of occurrent motives or states. ${ }^{35}$ An example of the first type is when we judge a person as bad, coward or dishonest. An example of the second type is when we judge "how inconsiderate someone was on a certain occasion or about how insensitive, dishonest or cowardly it was of him to do what he did." 36 The first type points to a general defect in the person's character while the second type points to a defect in the person's motivational structure on some particular occasion. ${ }^{37}$

Trianosky maintains that a negative deontic judgement cannot be imputed on a person who fails or even chooses not to perform a supererogatory act simply because in itself this non-performance is not worthy of blame. I cannot be blamed if I decide not to give my body organ to someone who needs it badly. The act of giving my body organ is a supererogatory act. However, Trianosky argues that a negative aretaic judgement is still possible for the non-performance of a supererogatory act. As a matter of fact, the omission of supererogatory act is usually vulnerable to negative aretaic judgement. ${ }^{38}$ It is because as he would explain, the person can still have less-than-virtuous or even vicious motive for this nonperformance. He cites a hypothetical example of a person who declines to participate in a charitable cause for a reason of complete lack of interest in helping or in pursuit of a trivial personal desire. Given these motives, Trianosky grants that a person may judge the non-performer to be insensitive, uncaring or callous. The choice not to help is permissible but the motivational structure is open to negative aretaic judgements. On this connection, Mellema observes that "sometimes people have an opportunity to be of service to others and they react with total indifference." 39 For Trianosky, therefore, one's failure to pursue a non-obligatory moral ideal is still open to a negative judgment, if not of the act itself, at the very least, of the character of the moral agent. Probably, it is a reason why we sometimes judge people as swapang

${ }^{34}$ Ibid., 29.

35 Ibid., 29.

${ }^{36}$ Ibid., 29.

37 Ibid., 29.

${ }^{38}$ For Gregory Mellema's interpretation of Trianosky's account, see Gregory Mellema, "Moral Ideals and Virtue Ethics," in Journal of Ethics 14 (2010), 177; 173-180.

${ }^{39}$ Ibid., 177.

(C) 2017 Franz Giuseppe F. Cortez https://www.kritike.org/journal/issue 21/cortez december2017.pdf ISSN 1908-7330 
(greedy) or matigas ang puso (hard-hearted, callous) - judgments of character even though they are not really morally obliged to perform a positive action.

Moreover, Trianosky notes the potential hypocrisy and superficiality when one fails to perform a supererogatory act. When one is too much focused on the fulfillment of his/her obligation and the pharisaic observance of the letters of the law, he/she misses the opportunity to show authentic concern for the other. Genuine human concern begins usually when one reaches the boundaries of obligatory morality. The territory of duties and obligations is a poor panorama of authentic concern for the other. "In all likelihood, real concern for others is not defined by the same boundaries that define our obligations." 40 The challenge of genuine morality is in the performance of actions beyond duty, the one of going the extra mile, and of stretching one's moral imagination. In situations of frequent refusal to do what is supererogatory, a negative aretaic judgment of hypocrisy and superficiality is not inappropriate.

Another important point which is related to Trianosky's commentary on hypocrisy and supererogation is the notion of right. In a situation of supererogation, the person may quip that he/she has every right to perform or even not to perform a particular act. The said person is logically justified for making this claim. However, a deeper appreciation of the action and the claim may reveal that "the agent reveals a genuinely vicious motivation in his coldly calculated insistence on what is rightfully his." 41 The refusal to perform a supererogatory act may uncover a vicious or defective motivation "precisely because he is willing on the occasion in question to do only what morality requires him to do, and no more. If he is challenged to do any more on that occasion, he stands on his rights." 42

Along this view of Trianosky, we can analyze the act or practice of EPS. It can be granted that EPS is supererogatory as discussed earlier in this paper. It can further be granted that since it is supererogatory, then it is nonobligatory or optional. It is something good and noble and therefore, it is not forbidden. But its non-performance does not impute moral blame on the employer.

However, following the line of thought of Trianosky, I will argue that even if EPS is supererogatory that escapes negative deontic judgement, the refusal to practice it may still be vulnerable to negative aretaic judgement. Take for example a hypothetical case where Mr. Tan is an employer who follows the letters of the law by giving his employees the minimum wage and a decent working condition. Let us assume further that because of a good economy combined with the best efforts of his employees, his business rakes

\footnotetext{
40 Trianosky, "Supererogation, Wrongdoing, and Vice," 33.

${ }^{41}$ Ibid., 35.

${ }^{42}$ Ibid., 35.
}

(c) 2017 Franz Giuseppe F. Cortez

https://www.kritike.org/journal/issue 21/cortez december2017.pdf

ISSN 1908-7330

(c) BY-NC-ND 
in profits that are much, much more than Mr. Tan is expecting. More so, let us assume that the profits that come in can pay not only the efforts and risks of the owner but also the provision for business expansion and diversification. The whole point of all these assumptions is that there is still enough fund that can be shared to the employees. The employees approached Mr. Tan to ask for bonuses (in this case, it is a share in the profits). If Mr. Tan does not want to share, you will not expect him to say it outright. He may sugarcoat his explanation by making some excuses or even by outright lying. Why can't Mr. Tan directly tell the employees that they don't have any right towards the said profit? He might be apprehensive that his best employees might leave him. But let us assume that Mr. Tan is so sure that he can always get new and replace the old. This time, he may be more frank and direct. But the employees are within reason to make a negative judgment if not of the act of not sharing the profit but at least a negative judgement of the motivation and character of this employer. Mr. Tan can always go back to the terms and conditions of the contract and the employees will not contest this defense. However, words such as swapang (greedy), walang puso (hard-hearted), manhid (insensitive), and gahaman (avaricious) can be labeled against the very character of Mr. Tan. Thus, the non-performance of profit sharing which is admittedly supererogatory (and therefore, optional and non-obligatory) is not completely immune from a negative aretaic judgment.

It may further be suggested that Mr. Tan's conscientious and faithful obedience to the law and to common morality is bordering on hypocrisy and superficiality. By refusing to share the fruits of the combined efforts of labor and capital fortunately situated in sound economic fundamentals, this employer operates within a philosophy of business that is fixated with profitmaximization and self-interested behavior. Mr. Tan only shows concern towards his employees not because he is really after their welfare but only because he can get something from them. There is "no real human concern in his heart." 43 Employees are objects to be used. They are commodities that are easily replaceable. They are means towards the end of profit-maximization. To judge that one is superficial and/or hypocrite points again not to the act itself but to the very character of the agent. And this judgement of superficiality of Mr. Tan is a by-product of his very refusal to cross the border of the obligatory in order to enter the realm of the supererogatory, that is, sharing the profits to his employees.

Finally, we can further reflect on the connection between EPS and the right of the employer not to share. When Mr. Tan is asked to explain why he chooses not to share, he can always invoke his right. "I don't have to share if I don't want to." "I am standing within my rights both legally and morally."

${ }^{43}$ Ibid., 34.

(C) 2017 Franz Giuseppe F. Cortez https://www.kritike.org/journal/issue 21/cortez december2017.pdf ISSN 1908-7330 
"I have every right not to share because I have every right to the profits of my business." Who can contest these claims of Mr. Tan? In a society that emphasizes individual rights, who can blame him? But what is questionable about this insistence on rights is the myopic and "legalistic attitude toward morality by asserting (one's) rights." ${ }^{44}$ Given for example the controversy of the legally-mandated minimum wage or the one-sidedness of legal contracts that employees "freely and willingly" enter, ${ }^{45} \mathrm{Mr}$. Tan's unsympathetic insistence on his right to profits is myopic and legalistic. Again, the judgement is not on the action of not sharing but on the very character of an employer who is cold, calculated, rights-obsessed and law-fixated.

\section{The Must and the Ought}

Scholars of ethics call attention to "acts which are not obligatory to perform but nevertheless blameworthy to omit." 46 The examples are already growing. As early as 1973, Aurel Kolnai argues that even though one is not morally obliged to forgive, he/she has the quasi-obligation to forgive somebody who eventually has a conversion of heart. Failing to forgive in this instance is worthy of moral blame. ${ }^{47}$ In an earlier essay, Claudia Card argues that even though one is not morally obliged to show mercy to an offender, there are some cases in which mercy seems intuitively appropriate. Card cites specific cases involving poetic justice that happens to the offender, or the offender is taken advantage of, or by the passage of time the offender has done something which is far more significant on his character as a whole than does his offense. ${ }^{48}$ In the context of friendship, Neera Badhwar believes that even if one has no moral obligation to do certain things such as forgiveness and generosity, a friend ought to be forgiving and generous in the name of authentic friendship. ${ }^{49}$ Then, John Whelan stresses the difference between "what I am morally required to do from what I morally ought to do even

${ }^{44}$ Ibid., 34.

45 "It is the employer who has the power to dictate contractual terms unless they have been fixed by collective bargaining. Individuals, except when they are highly sought after, have little scope to vary the terms of the contract imposed upon them by employers." Michael Armstrong and Helen Murlis, Reward Management: A Handbook of Remuneration and Strategy and Practice (London: Kogan Page, 2007), 54.

${ }^{46}$ Gregory Mellema, "Business Ethics and Doing What One Ought to Do," in Journal of Business Ethics 13 (1994), 149; 149-153.

${ }^{47}$ Aurel Kolnai, "Forgiveness," in Proceedings of the Aristotelian Society, 74:1 (1974), 91106.

${ }^{48}$ Claudia Card, "On Mercy," in The Philosophical Review 81:2 (1972), 187-207; $200 \mathrm{ff}$.

49 Neera K. Badhwar, "Friendship, Justice and Supererogation," in American Philosophical Quarterly 22:2 (1985), 123-131.

(c) 2017 Franz Giuseppe F. Cortez

https://www.kritike.org/journal/issue 21/cortez december2017.pdf

ISSN 1908-7330

(c) BY-NC-ND 
though I am not required to do it." 50 Among other examples, he concludes that charitable giving in specific circumstances qualifies as a moral ought. $\mathrm{He}$ says: "What do we owe the poor? If the question means what are we obligated to give to private charities which benefit the poor, then the answer is nothing: no one and no government may demand that we contribute to charity. But if it means what ought we to do about hunger and poverty in addition to paying taxes, then the answer is that most of us ought to give to charities which are trying to eliminate it." 51 Finally, Gregory Mellema pursues this line of argument and applies it in specific cases in the business and professional setting. One such example is that of a business owner who ought to pay a contractor who erroneously repaired the former's driveway. The error is on the contractor because the business owner did not hire him. But because the business owner has the intention to repair it after all, then he ought to pay (even though he is not required to pay) a certain amount to the contractor. ${ }^{52}$

The main point of this group of moral theorists is that there are actions that one ought to perform even if these actions are not morally obligatory. In other words, these thinkers accept the difference between the must and the ought. Between the obligatory and the optional, there is such thing as a quasi-obligatory. ${ }^{53}$ It can be granted that the must is stronger than the ought. If there is an imputation of moral blame in the performance or nonperformance of what is obligatory, blameworthiness is also labeled in the performance or non-performance of the quasi-obligatory. But in the case of the latter, it is granted that the degree of blameworthiness is lesser but not zero. ${ }^{44}$ And the violation of a must deserves an explanation, an apology or a compensation. However, the violation of the ought is relegated to persuasion and criticism. ${ }^{55}$

In the context of my topic at hand, can we now say that there are instances when an employer ought to share (even though he is not required to share) his profits to his employees? For me, the answer is in the affirmative. I can at least think of two instances. First, consider the hypothetical case of Mr. Santos, an owner of a start-up business, who gathers his employees and tells them that they must do their best for the sake of the business and that the success of the business also means the success of everyone involved in it. Indeed, after 5 years the business is dramatically successful. Even if there is no written contract or there is no direct promise, the employees have the right

${ }^{50}$ John Whelan, "Famine and Charity," in The Southern Journal of Philosophy, 29:1 (1991), $149-166$.

${ }^{51}$ Ibid., 165.

${ }^{52}$ Gregory Mellema, "Business Ethics and Doing What One Ought to Do," 150.

${ }^{53}$ Gregory Mellema, "Quasi-Obligation and the Failure to Be Virtuous," in Journal of Social Philosophy 24:2 (1993), 176-185.

${ }_{54}$ Gregory Mellema, The Expectations of Morality (New York: Rodopi, 2004), 6-7.

55 Whelan, "Famine and Charity," 152. 
to expect a share in the profit (in any form). ${ }^{56}$ Notice, that because of the absence of a written contract coupled with a vague and unsure promise, Mr. Santos is not legally and morally obliged to share. But the employees' expectation flowing from a weak or vague promise is not inappropriate. It can be granted that the degree of blameworthiness on the part of Mr. Santos is not that strong. But following Mellema's thought on the necessity of putting degrees to blameworthiness, I think it is also not zero. Furthermore, the employees cannot demand Mr. Santos to explain, apologize or compensate for telling a very general and vague statement. But these employees are justified to persuade and/or criticize this employer. It is reasonable for them to expect a share in the profit that can come in many forms or schemes since the business succeeds tremendously.

The second instance is a fictitious scenario wherein a certain business owner Mr. Smith whose business is prospering significantly since it started 20 years ago has never shared his profit even at least once. He gives to his favorite charity. He pays his taxes faithfully. He gives the minimum wage to most of his employees while he follows the prevailing rate in the industry for his middle and top managers. He creates an incentive system because he believes that it is an efficient way to maximize employee performance which will eventually turn into more profits for him alone. But he never makes any written or verbal promise to his employees that he will share his profits simply for the sake of sharing the profits. Again, Mr. Smith has no legal and moral obligation to share his profits to the employees. However, given these specific circumstances, I think Mr. Smith ought to share his profits in the name of charity towards his employees. Following Whelan's argument that one ought to give to charity in some specific circumstances, Mr. Smith should consider that the majority of his employees receive only the minimum wage which is way, way below the living wage. His act of charity ought to extend first to his own employees (who can be assumed to be living with a meager income) before or as it simultaneously extends to his favorite charity. The incentive system is not enough for two reasons. First, it is not an act of charity. It is established to maximize profits. It is not really for the employees. It is still for an egoistic pursuit. Second, incentive systems usually favor some and discriminate others. In an incentive system, not everyone may really benefit in the success of the business. Whelan observes further that "most of us hold people liable for blame if they do not sometimes give to charity." 57 It can follow as well that Mr. Smith can be held to be liable for blame if he does not sometimes share his profit to his employees. Again, this sharing does not refer

\footnotetext{
56 "A great many companies which have never considered profit sharing are now giving a Christmas bonus to employees at the end of the year. This is profit sharing of a sort, of course." Wheeler, Jr., "How I Would Introduce a Profit Sharing Plan to a Board of Directors," 15.

57 Whelan, "Famine and Charity," 164.
}

(c) 2017 Franz Giuseppe F. Cortez

https://www.kritike.org/journal/issue 21/cortez december2017.pdf

ISSN 1908-7330

(c) BY-NC-ND 
to the incentive system because of the motive of Mr. Smith and the potential weaknesses of an incentive system. Mr. Smith is not obliged but he ought to share. ${ }^{58} \mathrm{He}$ can re-calibrate both his motives for incentivizing and the incentive scheme itself to fulfill the ought-ness of charity towards his employees. The blameworthiness for not sharing is lesser than the blameworthiness for the non-performance of an obligatory act. Nevertheless, moral blame is still imputed in the omission of sharing the profit. ${ }^{59}$

A final point can be argued by Mr. Smith that he does not establish his business to be charitable to his employees. He enters business to gain more profits. And after all, isn't it that profit-maximization (not charity) is the purpose of business? ${ }^{60}$ To respond to this, it can be argued that Mr. Smith's subjective motive is not aligned with the objective purpose of business. Many scholars have already stressed this point. For example, Ronald Duska clarifies the confusion between motive and purpose. The purpose of business is the provision of goods and services and this purpose is independent from the plethora of motives that individual business owners can have. ${ }^{61}$ Paul Camenisch argues for the twin essentials of business: the provision of goods and services and that it is done with the intention of making a profit. ${ }^{62}$ For his part, Robert Solomon stresses that profit is an incentive and a means; it is not

58 "That is, one ought to be charitable-it is wrong on moral grounds not to bealthough one has no obligation as such to be charitable; others cannot justifiably press a claim for charity as their right." Card, "On Mercy," 196.

59 In my electronic communication with Gregory Mellema dated August 1, 2017, he agrees that an act of EPS may be morally expected and might be blameworthy to omit.

60 This position is also glimpsed in some scholarships. For example, the American sociologist and economist Thorstein Veblen says: "The motive of business is pecuniary gain, the method is essentially purchase and sale. The aim and usual outcome is an accumulation of wealth. Men whose aim is not increase of possessions do not go into business, particularly not on an independent footing." Thorstein Veblen, Theory of Business Enterprise (New York: Charles Scribner's Sons, 1904), 20.

One of the most oft-quoted text that seems to support this position is that of coming from Milton Friedman. He says that "[there] is one and only one social responsibility of business - to use its resources and engage in activities designed to increase its profits so long as it stays within the rules of the game, which is to say, engages in open and free competition without deception or fraud." Milton Friedman, "The Social Responsibility of Business is to Increase Its Profits," in The New York Times Magazine (New York: The New York Times Company, 13 September 1970).

61 "... the purpose of business is not to benefit me primarily. It is not to make a profit. If doing business rewards me with a profit, I will be inclined to participate in it, but the purpose of business - why society allows it to exist in its profit-oriented form - is to provide goods and services." Ronald Duska, Contemporary Reflections on Business Ethics (The Netherlands: Springer, 2007), 10.

62 "Business's primary function ... is the producing of goods and services to sustain and enhance human existence. Profit then, given the way business functions in the marketplace, becomes one of the necessary means by which business enables itself to continue supplying such goods and services." Paul Camenisch, "Business Ethics: On Getting to the Heart of the Matter," in Business and Professional Ethics Journal 1:1 (1981), 55-69. 
the end of business. ${ }^{63}$ While the management guru Peter Drucker quips that "profit is not the explanation, cause, or rationale of business behavior and business decisions, but the test of their validity." ${ }^{64}$ This clarification on the true and objective purpose of business strengthens the argument for a practice of charity that Mr. Smith ought to extend to his employees. Again, even if he is not obliged to share the fruits of the prosperity of his business, the ought-ness of charity calls him to share even if not in a regular basis.

The point of this discussion is that there are instances when employee profit sharing carries a quasi-obligatory nature. These few cases are not supererogatory in character. They are not optional even if they are not completely obligatory. They can be appropriately called quasisupererogatory. ${ }^{65}$ They carry the weak and light version of ought-ness and not the strong and heavy imputation of the must like for example when we say that Mr. Smith must pay the minimum wage or must assure a safe and healthy working condition for his employees.

\section{Concluding Remarks}

This paper attempts to provoke a debate by reviving the question: "Is employee profit sharing a moral obligation or a moral option?" Normative arguments grounded on justice, equity, rights and general welfare are necessary, but they are not sufficient to account for the ethics of employee profit sharing.

An exploration of meta-ethical approach is suggested on this paper. Using this approach, it becomes apparent that the said question is misleading after all for two reasons. First, because of its tendency to subsume into one set all practices of employee profit sharing. The ethics of EPS cannot be reduced to a blanket rejection of the obligatory or non-obligatory character of the said practice. Rather, there is a need to move from the ethic of practice into the ethic of action taking into consideration the plurality of particularities involved when judging the act of each employer. These particularities include the employer's motives and the various circumstances that necessitate careful

\footnotetext{
${ }^{63}$ "To be sure, a business does aim to make a profit, but it does so only by supplying quality goods and services, by providing jobs, and by fitting in with the community. To single out profits rather than productivity or public service as the central aim of business activity is to ask for trouble. And profits as such are not the end or the goal of business activity: profits get distributed and reinvested. Profits are a means of building the business and rewarding employees, executives, and investors." Robert Solomon, "Business and the Humanities: An Aristotelian Approach to Business Ethics," in Business as a Humanity ed. by Thomas Donaldson and R. Edward Freeman (New York: Oxford University Press, 1994), 60-61.

${ }^{64}$ Peter F. Drucker, Management, revised ed., ed. by Joseph Maciariello (HarperCollins e-books, 2008), 97.

${ }^{65}$ Gregory Mellema, “Quasi-supererogation,” in Philosophical Studies 52 (1987), 141-150.

(c) 2017 Franz Giuseppe F. Cortez

https://www.kritike.org/journal/issue 21/cortez december2017.pdf

ISSN 1908-7330
}

(c) BY-NC-ND 
consideration towards making an ethical judgement. This observation further confirms the reality that the business world is so complex and challenging that a reductionist and generalist moral judgment will oftentimes be rendered incomplete and impoverished.

The second reason why the question is misleading is because of its bifurcatory character. Combining justice and general welfare arguments with an extended analysis of the notion of moral obligation and moral option may lead one to conclude that even if employee profit sharing is rendered to be morally non-obligatory, it is an impoverishment of moral life and a myopia of moral judgment to relax and relegate this action and practice into the category of the morally optional. To put it simply, to make a categorical choice between moral obligation and moral option in the many cases of EPS would undermine the complexities and nuances of the moral life in the business world.

Admittedly, employee profit sharing is not a legal obligation in almost all societies. (The legal system of France is a curious exception as I mentioned in the earlier part of this paper.) Whether EPS is a moral obligation is not a settled issue at all. We have not yet achieved a level of universal recognition that employees must have a moral right to have a share in the profits of the business that they have helped to generate. This analysis is a contribution on this ongoing philosophical debate. It further alerts students of business ethics on how to probe the moral dimension of a business practice.

Department of Philosophy, University of Santo Tomas, Philippines

\section{References}

AFIGEC, "Profit Sharing Plan in France," in AFIGEC: Expert Comptable and Conseil, <http://www.afigec.com/data/en/pdf/24/profit-sharing-planin-france.pdf $>, 7$ February 2017.

Armstrong, Michael and Helen Murlis, Reward Management: A Handbook of Remuneration and Strategy and Practice (London: Kogan Page, 2007).

Badhwar, Neera K., "Friendship, Justice and Supererogation," in American Philosophical Quarterly 22:2 (1985).

Baron, Marcia, "Kantian Ethics and Supererogation," in The Journal of Philosophy 84:5 (1987).

Cahill, Noel, "Profit Sharing, Employee Share Ownership and Gainsharing: What Can They Achieve?" (Dublin: National Economic and Social Council, 2000).

Camenisch, Paul, "Business Ethics: On Getting to the Heart of the Matter," in Business and Professional Ethics Journal 1:1 (1981).

Card, Claudia, "On Mercy," in The Philosophical Review 81:2 (1972).

(C) 2017 Franz Giuseppe F. Cortez

https://www.kritike.org/journal/issue 21/cortez december2017.pdf

ISSN 1908-7330

(cc) BY-NC-ND 
Cunningham, Francis, The Christian Life (Oregon: WIPF and Stock, 1959).

D'Art, Daryl, Economic Democracy and Financial Participation: A Comparative Study (London: Routledge, 1992).

Drucker, Peter F., Management, revised ed., ed. by Joseph Maciariello (HarperCollins e-books, 2008)

Duska, Ronald, Contemporary Reflections on Business Ethics (The Netherlands: Springer, 2007).

Emmet, Borris and United States Bureau of Labor Statistics, Profit Sharing in the United States: Bulletin of the United States Bureau of Labor Statistics 208 (Washington, D.C.: Government Printing Office, June 1916).

Friedman, Milton, "The Social Responsibility of Business is to Increase Its Profits," in The New York Times Magazine (New York: The New York Times Company, 13 September 1970).

Georgescu, Stefan and Loredana Bosca, "Management's Duty towards Employees: A Business Ethics Approach," in Proceedings of the $7^{\text {th }}$ International Management Conference (Bucharest, Romania: 7-8 November 2013).

Giddings, Franklin H., "The Theory of Profit-Sharing," in The Quarterly Journal of Economics 1:3 (1887).

Heyd, David, Supererogation: Its Status in Ethical Theory (Cambridge: Cambridge University Press, 1982).

Jackson, M.W., "Above and Beyond the Call of Duty," in Journal of Social Philosophy 19:2 (1988).

Kolnai, Aurel, "Forgiveness," in Proceedings of the Aristotelian Society, 74:1 (1974).

McCloskey, H.J., Meta-Ethics and Normative Ethics (Dordrecht: SpringerScience+Business Media, 1969).

Mellema, Gregory, "Business Ethics and Doing What One Ought to Do," in Journal of Business Ethics 13 (1994). "Moral Ideals and Virtue Ethics," in Journal of Ethics 14 (2010).

"Quasi-Obligation and the Failure to Be Virtuous," in Journal of Social Philosophy 24:2 (1993).

"Quasi-supererogation," in Philosophical Studies 52 (1987)

The Expectations of Morality (New York: Rodopi, 2004).

Quill, James H., Profit Sharing - A Means of Economic Cooperation between Labor, Management, and Government (M.S. Thesis, Chicago: Loyola University, 1954).

"Report on Profit Sharing and Co-Partnership in the United Kingdom" (United Kingdom Ministry of Labour, 1920).

Reynolds, John, Sharing Profits: The ethics of remuneration, tax and shareholder returns (UK. Palgrave MacMillan, 2015).

(c) 2017 Franz Giuseppe F. Cortez

https://www.kritike.org/journal/issue 21/cortez december2017.pdf

ISSN 1908-7330

(cc) BY-NC-ND 
Rooney, Gerard, "The Right of Workers to Share in Ownership, Management, and Profits," in Catholic Theological Society of America: Proceedings of the Eighteenth Annual Convention (St. Louis, Missouri, 24-27 June 1963).

Santore, Anaxos, "Profit Sharing," in Encyclopedia of Small Business, $4^{\text {th }}$ ed., ed. by Virgil L. Burton III (Michigan, USA: GALE Cengage Learning, 2010).

Sheldon, Oliver, The Philosophy of Management, ed. by Oliver Sheldon, vol. 4 of The Philosophy of Management (London: Routledge, 2003).

Simmons, A. John, Moral Principles and Political Obligation (Princeton: Princeton University Press, 1979).

Solomon, Robert, "Business and the Humanities: An Aristotelian Approach to Business Ethics," in Business as a Humanity ed. by Thomas Donaldson and R. Edward Freeman (New York: Oxford University Press, 1994).

Stack, Jack, "The Problem with Profit-Sharing," in Inc. (1 November 2000), $<$ https://www.inc.com/magazine/19961101/1864.html >, 1 August 2017.

Trianosky, Gregory, "Supererogation, Wrongdoing, and Vice: On the Autonomy of the Ethics of Virtue," in The Journal of Philosophy 83:1 (1986).

Ugarkovic, Marija, Profit Sharing and Company Performance (Wiesbaden, Germany: Deutscher Universitats-Verlag, 2007).

Urmson, James O., "Saints and Heroes," in Essays in Moral Philosophy, ed. by A.I. Melden (Seattle: University of Washington Press, 1958).

Uvalic, Milicia, The Pepper Report: Promotion of Employee Participation in Profits and Enterprise Results in the Member States of the European Community (Luxembourg: Office of the Official Publications of the European Communities, 1991).

Veblen, Thorstein, Theory of Business Enterprise (New York: Charles Scribner's Sons, 1904).

Weitzman, Martin, The Share Economy: Conquering Stagflation (Cambridge: Harvard University Press, 1984).

"The Simple Macroeconomics of Profit Sharing," in American Economic Review 75 (1985).

Wheeler, W.H. Jr., "How I Would Introduce a Profit Sharing Plan to a Board of Directors," in Michigan Business Review 3-4 (January 1952).

Whelan, John, "Famine and Charity," in The Southern Journal of Philosophy, 29:1 (1991). 